\title{
Pengembangan Buku Suplemen Kurikulum 2013 berbasis Flipbook Tema Kearifan Lokal Kalsel untuk Siswa Kelas V SD di Masa Pandemik Covid-19
}

\author{
${ }^{1}$ Yudha Adrian, ${ }^{2}$ Rahidatul Laila Agustina \\ ${ }^{1,2}$ Prodi PGSD, STKIP PGRI Banjarmasin, Indonesia
}

Email: ${ }^{1}$ yudhaadrian@ @stkipbjm.ac.id, ${ }^{2}$ rahidatullailaagustina@stkipbjm.ac.id

\begin{tabular}{l}
$\overline{\text { Tersedia Online di }}$ \\
\hline http://www.jurnal.unublitar.ac.id/ \\
index.php/briliant
\end{tabular}

Sejarah Artikel

Diterima pada 1 Oktober 2020

Disetuji pada 5 November 2020

Dipublikasikan pada 30

November 2020

Hal. 769-780

\section{Kata Kunci: \\ $\overline{\text { Buku Suplemen; Flipbook; }}$ \\ Kalsel; Kearifan lokal}

\section{DOI:}

http://dx.doi.org/10.28926/briliant .v3i4.562

\begin{abstract}
Abstrak: Tujuan penelitian ini mengembangkan buku suplemen kurikulum 2013 tema kearifan lokal Kalsel yang valid dan menarik. Suplemen pembelajaran yang dikembangkan berbentuk flipbook. Flipbook menampilkan gerakan-gerakan yang seolah-olah membuka dan menutup halaman buku. Tema kearifan lokal Kalsel berupa pandangan hidup dan ilmu pengetahuan yang berwujud pada aktivitas dalam kehidupan sehari-hari. Tema Kearifan lokal Kalsel adalah tema "Banuaku". Penelitian ini menggunakan model pengembangan Four D, dengan tahap (define, design, develop, disseminate), dengan modifikasi dengan meniadakan developmental testing. Dengan alasan, keadaan masa pandemik Covid-19 membatasi ruang gerak dalam penelitian ini. Produk ini divalidasi oleh ahli materi, ahli media, ahli bahasa, validasi pengguna guru dan siswa. Instrumen pengumpulan data berupa angket dibagikan kepada validator ahli, dan validator pengguna. Hasil validasi ahli materi dengan skor 67, ahli bahasa 56, dan ahli media 68
\end{abstract}

Validasi pengguna guru dengan skor 71,5, 82, 76 dan 81 dengan kriteria (valid). Validasi pengguna siswa dengan nilai 93, 100, 100, dan 100. Hasil validasi ahli dan pengguna menunjukkan valid, menarik, dan layak digunakan di kelas V sekolah dasar. Produk ini digunakan oleh guru sebagai alternatif sumber belajar siswa.

\section{PENDAHULUAN}

Wabah Covid-19 masuk ke Kota Banjarmasin berimbas pada segala aspek kehidupan. Salah satu aspek yang terdampak wabah Covid-19 adalah aspek pendidikan. Untuk mengantisipasi penularan Covid-19, pemerintah menerbitkan kebijakan berupa pembatasan social berskala besar (PSBB) (Jamaluddin, et al. 2020). Hal ini berimbas langsung pada kegiatan pembelajaran yang dilaksanakan khususnya di sekolah dasar. Pada tanggal 24 Maret 2020 Mendikbud menerbitkan kebijakan pelaksanaan pembelajaran dirumah melalui daring (dalam jaringan)/internet untuk memberikan pengalaman bermakna (Astini 2020).

Secara tidak langsung, kondisi masa pandemik Covid-19 menuntut guru untuk inovatif. Inovasi pembelajaran idealnya memanfaatkan teknologi informasi yang berkembang secara pesat. Pemanfaatan teknologi informasi berdampak pada system pendidikan mengikuti perubahan zaman, yang awalnya bersifat konvensional secara berangsur-angsur mengarah kepada sistem modern, IT, atau digital (Kristiawan, 2014). Idealnya, seorang guru mampu memanfaatkan teknologi informasi dengan menggunakan perangkat komputer, PC, dan smartphone dalam 
melaksanakan proses pembelajaran dalam jaringan. Karena, dalam pembelajaran daring selalui memanfaatkan perangkat berbasis teknologi informasi. Perangkat yang paling sederhana digunakan dalam pembelajaran daring salah satunya smartphone. Smarphone digunakan untuk menyampaikan informasi kepada siswa.

Proses pembelajaran di masa pandemik Covid-19, kegiatan pembelajaran bersifat daring seyogyanya mengacu pada kebijakan pemerintah. Artinya, kegiatan pembelajaran tidak bertolak belakang dengan kebijakan yang ditetapka oleh pemerintah khususnya dinas pendidikan. Secara ideal, proses pembelajaran daring tetap mengacu (Permendiknas No. 22 2016) pembelajaran harus interaktif, inspiratif dan bermakna. Untuk mengaktualisasi proses pembelajaran aktif, idealnya guru menerapkan pembelajaran mengacu pada pendekatan student centered learning. Dengan kata lain, kegiatan pembelajaran menitik beratkan kepada siswa. Siswa aktif dalam pembelajaran, guru aktif dalam menjadi fasilitator pembelajaran.

Pada masa pandemik Covid-19, pembelajaran yang interaktif tidak mudah untuk dilaksanakan. Hal ini disebabkan karena guru tidak secara langsung dapat berinteraksi langsung dengan siswa. Terdapat pembatas, antara guru dan siswa dalam menyampaikan atau memfasilitasi kegiatan belajar. Apalagi, kegiatan pembelajaran hanya mengandalkan daring untuk mentrasformasi ilmu pengetahuan kepada siswa. Guru tidak dapat secara langsung bertindak untuk menggugah atau menstimulasi siswa untuk aktif dalam kegiatan pembelajaran. Oleh karena itu, guru harus inovatif dalam melaksanakan kegiatan pembelajaran yang notabene bersifat daring.

Dalam praktik di lapangan, guru memanfaatkan salah satu media sosial berbasis daring dalam melaksanakan pembelajaran. Aplikasi yang digunakan adalah WhatsApp. Aplikasi WhatsApp dapat dijadikan sebagai tempat diskusi untuk memecahkan masalah, pertanyaan, dan jawaban (Kusuma and Hamidah 2020). Untuk itu, guru dapat memanfaatkan teknologi dalam melaksanakan pembelajaran dengan grup WhatsApp. Pada grup WhatsApp, guru dapat memberikan materi yang akan dipelajari oleh siswa. Selain itu, guru dapat memberikan penugasan secara berkelompok kepada kelompok siswa tanpa terkendala jarak. Dengan demikian, pembelajaran masih dapat dilaksanakan melalui media grup WhatsApp yang dibuat oleh guru dan diikuti oleh siswa. Sebenarnya, kegiatan pembelajaran tidak sebatas menggunakan media social. Karena semakin lama menggunakan media sosial, memungkinkan siswa menjadi bosan, sehingga pembelajaran terlihat seperti pemberian tugas saja. Hal akan memberikan dampak negatif bagi kelangsungan kegiatan pembelajaran berbasis daring. Memang tidak bisa di pungkiri, segala kemungkinan akan dapat terjadi di masa Pandemik Covid-19 seperti sekarang ini. oleh karena itu, guru ditantang untuk inovatif dalam melaksanakan pembelajaran.

Pada pembelajaran masa pandemik, guru harus mengolah dan mempersiapkan bahan ajar yang menarik agar siswa tidak jenuh dalam mengikuti pembelajaran. Pada kegiatan pembelajaran, biasanya siswa dan guru menggunakan buku yang telah diberikan oleh pemerintah. Konten buku tersebut tidak secara rinci membahas khasanah kearifan lokal Kalsel. Oleh karena itu, sangatlah penting mengembangkan buku suplemen yang menyajikan materi kearifan lokal Kalsel agar siswa tidak hanya memahami materi secara global.

Kearifan Lokal (local wisdom) merupakan pandangan hidup, ilmu pengetahuan, dan berbagai strategi kehidupan yang berwujud aktivitas yang

770 BRILIANT: Jurnal Riset dan Konseptual Volume 5 Nomor 4, November 2020 
dilakukan oleh masyarakat setempat untuk menjawab berbagai masalah dalam memenuhi kebutuhan mereka (Wagiran 2011). Kearifan lokal Kalsel dijadikan tema dalam suplemen pembelajaran. Tema suplemen pembelajaran ini adalah tema "Banuaku", yang bermakna wilayah tempat tinggalku. Konten yang terdapat dalam suplemen pembelajaran berkaitan dengan kearifan lokal dan potensi Kalsel yang diantaranya alat mencari ikan tradisional, perahu tambangan, lagu daerah Kalsel, hewan endemik, ekosistem, peran pahlawan Kalsel, serta proklamasi 14 Mei 1949.

Suplemen pembelajaran menjadi alternatif solusi yang diberikan oleh peneliti dalam berinovasi guna membantu guru pada masa pandemik Covid-19 yaitu dengan mengembangkan suplemen pembelajaran. Suplemen pembelajaran yang dikembangkan ini merupakan bahan ajar berbasis flipbook. Dalam bahasa Indonesia, flipbook adalah buku siswa dapat mempelajarinya secara mandiri. Sifat buku suplemen yang dikembangkan pada penelitian ini adalah buku teks penunjang pembelajaran. Buku teks penunjang merupakan buku teks pelengkap yang berguna untuk membantu buku teks utama (Prastowo 2014). Dalam praktiknya buku teks yang dikembangkan di belajar sesuai dengan materi dan kebutuhan para guru di lapangan.

Buku suplemen dikembangan oleh peneliti dengan memadukan aplikasi flipbook dalam menampilkan konten buku teks secara murni, menarik, dan tidak membosankan bagi guru dan siswa. Flipbook berupa buku virtual yang didalamnya dapat menampilkan materi buku suplemen secara keseluruhan. Flipbook dapat menampilkan gerakan-gerakan yang seolah-olah membuka dan menutup halaman buku, menampilkan gambar bergerak, dan memutar musik. Buku suplemen yang disajikan dalam flipbook diharapkan mampu mengatasi kejenuhan guru dan siswa dalam kegiatan pembelajaran secara. Materi yang terdapat pada flipbook ditampilkan pada layar PC atau laptop.

Secara empiris, pengembangan flipbook dinilai valid, dan praktis dalam penggunaannya. Hasil penelitian Listyarini, Saputra, \& Basyar (2018) dengan judul Pengembangan Media digital Book berbasis Flipbook Maker IPA kelas V di Sekolah Dasar menunjukkan hasil valid berdasarkan penilaian validator ahli. Selain itu, penilaian pengguna oleh siswa SDN Rejosari 3 Semarang dengan prosentase $100 \%$, sedangkan siswa SDN Bugangan 02 Semarang dengan prosenase 96,61. Hasil penelitian inilah menjadi bukti empiris yang menyatakan bahwa buku berbasis flipbook sangat baik digunakan di Sekolah Dasar. Tujuan penelitian ini untuk mengembangkan buku suplemen kurikulum 2013 tema kearifan lokal Kalsel yang valid dan menarik dipadukan flipbook untuk siswa kelas V Sekolah Dasar kota Banjarmasin.

\section{METODE}

Metode penelitian ini penelitian pengembangan dengan model pengembangan Four D (Define, Design, Develop, and Dissemination) (Thiagarajan, Semmel and Semmel, 1974). Dalam penerapannya, model pengembangan Four D dimodifikasi sesuai dengan kondisi dan kebutuhan dilapangan. Modifikasi dilakukan disebabkan masa pandemik Covid-19 yang menjadi kendala dalam implementasi tahapan model Four D. Tahapan modifikasi model pengembangan Four D meliputi: (Define, Design, Develop, and Dissemination). 
Tahap define meliputi 1). Melakukan analisis peserta didik (learner analysis). 2) melakukan (task analysis) analisis kompetensi yang harus dicapai oleh siswa. 3) menyusun (consept analysis) konsep pembelajaran sesuai dengan pola pendekatan saintifik. 4) menyusun (spesifying instructional objective) tujuan pembelajaran khusus sesuai kompentesi dasar.

Tahap design meliputi: 1) Menyusun matrik pengembangan buku suplemen pembelajaran yang terdiri atas kompetensi inti, kompetensi dasar, tujuan pembelajaran, variabel tema kearifan lokal Kalimantan Selatan, sub-variabel kearifan lokal Kalimantan Selatan, tema awal, tema yang dikembangkan, objek pada draft, dan draft materi. 2) Menyeleksi media atau objek (media selection) yang akan dimuat pada draft buku suplemen. 3) menentukan format (format selection) buku suplemen sesuai kebutuhan. 3) memulai mendesain (initial design) buku suplemen sesuai dengan sistematika buku ajar.

Tahap develop meliputi kegiatan expert appraisal dan developmental testing. Kegiatan expert appraisal adalah kegiatan memvalidasi produk melalui ahli materi, ahli media, ahli bahasa, dan pengguna. Kegiatan developmental testing adalah kegiatan uji coba produk terhadap subjek penelitian. Kegiatan ini ditiadakan karena proses pembelajaran masih bersifat daring. Ujicoba produk secara daring ditiadakan karena pihak sekolah belum memberikan izin.

Tahap disseminate adalah kegiatan menyebarluaskan produk yang sudah direvisi sesuai saran dan masukan validator. Produk final disebarluaskan tingkat gugus Kelayan Barat Banjarmasin, dengan mematuhi dan mempertimbangkan protokol kesehatan. Penyebarluasan produk melalui kegiatan KKG rutin yang dilaksanakan pada gugus Kelayan Barat Banjarmasin.

Dengan demikian, tahapan modifikasi model pengembangan Four D dengan meniadakan kegiatan ujicoba produk kepada subjek penelitian. Hal ini disebabkan pembelajaran dilaksanakan secara daring, serta seluruh kegiatan di sekolah tetap mematuhi protokol kesehatan masa pandemik Covid-19.

Tabel 1 Tahapan Model 4 D

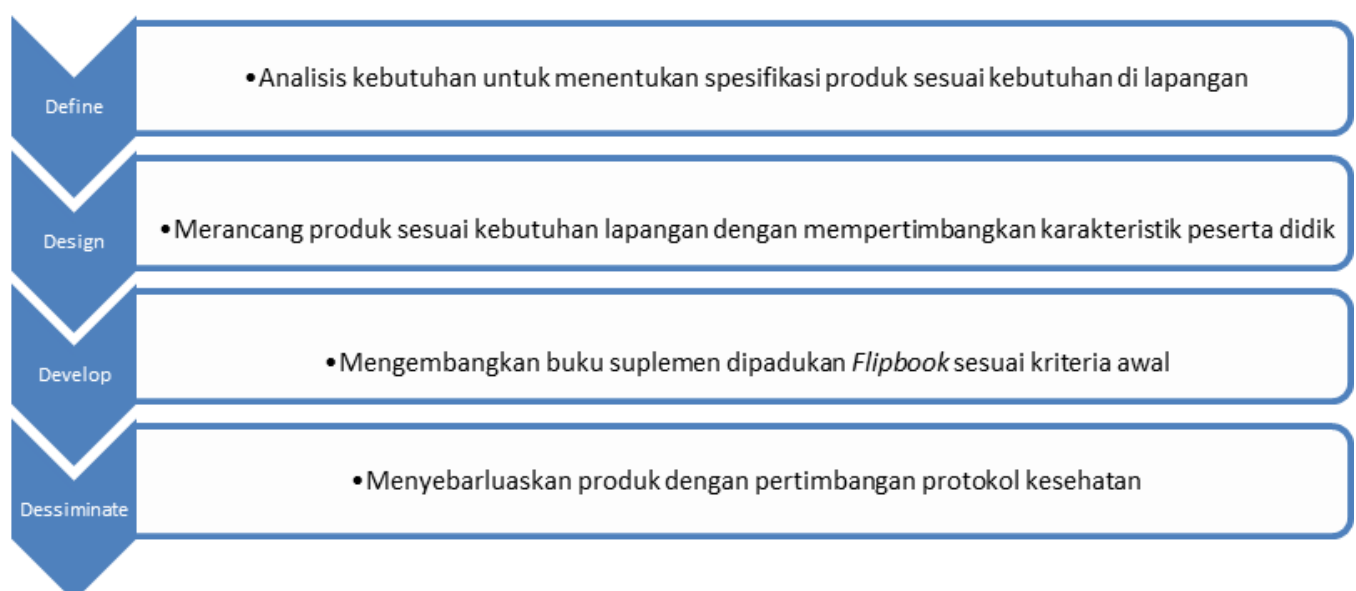

Subjek penelitian ini SDN Kelayan Barat 2 dan SDN Kelayan Barat 3 Banjarmasin. Data dikumpulkan melalui angket validasi ahli dan angket respon pengguna. Validator ahli dosen adalah dosen berlatar belakang Pendidikan Dasar. Pengguna adalah 2 guru kelas V SDN Kelayan Barat 2 dan SDN Kelayan Barat 3 Banjarmasin. Pengguna siswa adalah 4 siswa SDN Kelayan Barat 2 Banjarmasin.

772 BRILIANT: Jurnal Riset dan Konseptual Volume 5 Nomor 4, November 2020 
Uji coba produk tidak dilaksanakan karena pelaksanaan pembelajaran di rumah. Pihak sekolah tidak mengizinkan untuk mengumpulkan siswa di sekolah untuk mencegah penularan Covid-19. Data dikumpulkan hasil penilaian validator ahli dan pengguna. Data tersebut berbentuk kualitatif dan kuantatif. Data kualitatif diperoleh dari masukan dan komentar validator ahli dan pengguna. Data kuantitatif diperoleh dari skor angket yang diberikan kepada validator ahli dan pengguna. Jenis data yang dianalisis berupa kemenarikan dan kemenarikan oleh validator ahli materi, dan pengguna. Produk direvisi sesuai dengan masukan oleh validator dan pengguna. Produk tersebut adalah produk final penelitian.

\section{HASIL}

Penelitian ini merupakan penelitian pengembangan dengan menggunakan model $4 \mathrm{D}$. Adapun prosedur pengembangan $4 \mathrm{D}$ meliputi define, design, develop, dan disseminate secara terperinci dipaparkan sebagai berikut:

\section{Tahap Pendefinisian (define)}

Pada tahap pendefinisian meliputi sebagai berikut: 1). Melakukan analisis peserta didik (learner analysis). Analisis peserta didik melalalui studi pendahuluan yang dilakukan di SDN Kelayan Barat 2 dan SDN Kelayan Barat 3 Banjarmasin. Kegiatan ini melalui wawancara dengan kepala sekolah terkait kebutuhan guru kelas dalam proses pembelajaran. Selanjutnya, wawancara dengan guru kelas V terkait kebutuhan materi, sumber belajar, dan bahan ajar yang dibutuhkan oleh guru dalam membelajarkan kepada siswa. 2) melakukan (task analysis) analisis kompetensi yang harus dicapai oleh siswa. Analisis kompetensi pada buku guru kelas V tema "Ekosistem". 3) menyusun (consept analysis) konsep pembelajaran sesuai dengan pola pendekatan saintifik. 4) menyusun (spesifying instructional objective) tujuan pembelajaran khusus sesuai kompentesi dasar pada tema "Ekosistem". Kegiatan menyusun matrik pengembangan suplemen pembe: lajaran melalui diskusi guru kelas $\mathrm{V}$ dengan menaati protokol kesehatan yang ditetapkan di SDN Kelayan Barat 2 dan SDN Kelayan Barat 3 Banjarmasin.

\section{Tahap Perancangan (Design)}

Pada tahap perancangan akan menghasilkan draft awal buku suplemen pembelajaran kurikulum 2013. Kegiatan yang dilaksanakan yaitu: 1) Menyusun matrtik pengembangan buku suplemen pembelajaran yang terdiri atas kompetensi inti, kompetensi dasar, tujuan pembelajaran, variabel tema kearifan lokal Kalimantan Selatan, sub-variabel kearifan lokal Kalimantan Selatan, tema awal, tema yang dikembangkan, objek pada draft, dan draft materi. 2) Menyeleksi media atau objek (media selection) yang akan dimuat pada draft buku suplemen. 3) menentukan format (format selection) buku suplemen sesuai kebutuhan. 3) memulai mendesain (initial design) buku suplemen sesuai dengan sistematika buku ajar.

\section{Tahap Pengembangan (Developing)}

Pada tahap ini mengembangkan dengan menyusun materik pengembangan bahan ajar meliputi kompetensi inti, kompetensi dasar, tujuan pembelajaran, tema, subtema, objek, materi, dan evaluasi. Materik pengembangan suplemen pembelajaran tersebut menjadi acuan dalam mengembangkan prototype atau draft suplemen pembelajaran. Pada tahap pengembangan ini melalui satu kegiatan 
penting dengan metode expert appraisal. metode ini adalah kegiatan memvalidasi produk melalui ahli materi, ahli media, ahli bahasa. Validator ahli materi adalah Siti Aulia, M.Pd, dengan latar belakang Pendidikan Dasar. Ahli media yaitu Tety Nor Cholifah, M.Pd dengan latar belakang pendidikan S1 Teknologi Pendidikan, dan S2 Pendidikan Dasar. Validator bahasa yaitu Dr. Hj. Ida Rusdiana, M.Pd dengan latar belakang pendidikan bahasa Indonesia, serta riset beliau berhubungan dengan bahasa Indonesia dan bahasa Banjar. Adapun hasil validasi ahli materi, ahli media, dan ahli bahasa sebagai berikut:

Tabel 2 Kriteria Validasi

\begin{tabular}{|c|c|l|l|l|}
\hline Skor & \multicolumn{4}{|c|}{ Kriteria } \\
\hline $73<\bar{x} \leq 88$ & SB & Sangat baik & Valid & $\begin{array}{l}\text { Dapat digunakan tanpa } \\
\text { perbaikan }\end{array}$ \\
\hline $56<\bar{x} \leq 73$ & B & Baik & Cukup valid & $\begin{array}{l}\text { Dapat digunakan dengan } \\
\text { sedikit perbaikan }\end{array}$ \\
\hline $39<\bar{x} \leq 56$ & K & Kurang & Kurang valid & $\begin{array}{l}\text { Dapat digunakan dengan } \\
\text { perbaikan }\end{array}$ \\
\hline $22 \leq \bar{x} \leq 39$ & SK & Sangat kurang & Tidak valid & Tidak dapat digunakan \\
\hline \multicolumn{5}{|c|}{ Adopsi: Dahlia (2020) } \\
\hline
\end{tabular}

Diagram 1 Validasi Ahli

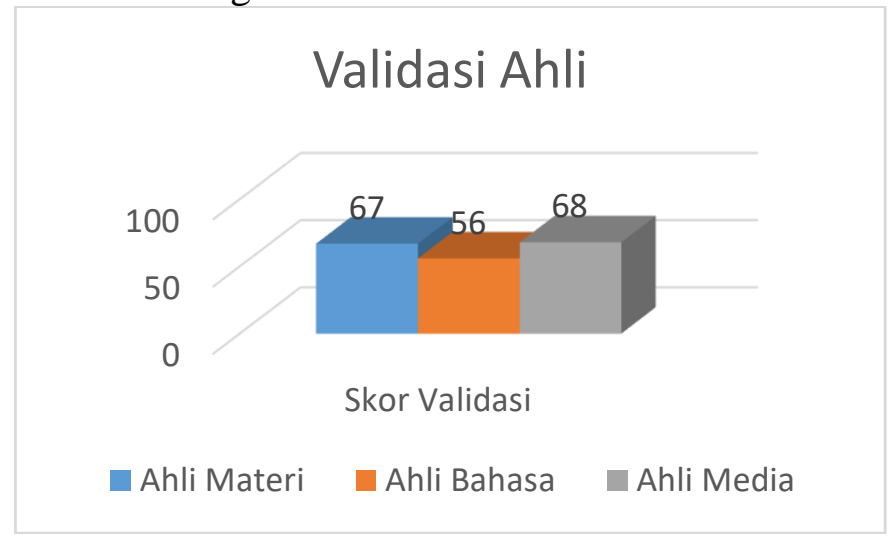

Diagram di atas merupakan hasil validasi ahli materi dengan skor 67 dengan kriteria (valid), ahli bahasa 56 dengan kriteria (valid), dan skor ahli media 68 (valid). Dengan demikian, penilaian oleh ahli materi, ahli bahasa, dan ahli media menunjukkan produk ini valid dan dapat digunakan.

Validator pengguna yaitu Farhat, S.Pd dan Pahdi Hernianor, S.Pd adalah guru SDN Kelayan Barat 3. Mufida, S.Pd dan Syamsiah, S.Pd adalah SDN Kelayan Barat 2 Banjarmasin. Jumlah guru sebagai validator pengguna empat orang. Sedangkan validator pengguna berasal dari SDN Kelayan Barat 2 Banjarmasin sebanyak empar orang siswa kelas V. secara rinci dipaparkan pada diagram dibawah ini: 
Diagram 2 Hasil Validasi Guru

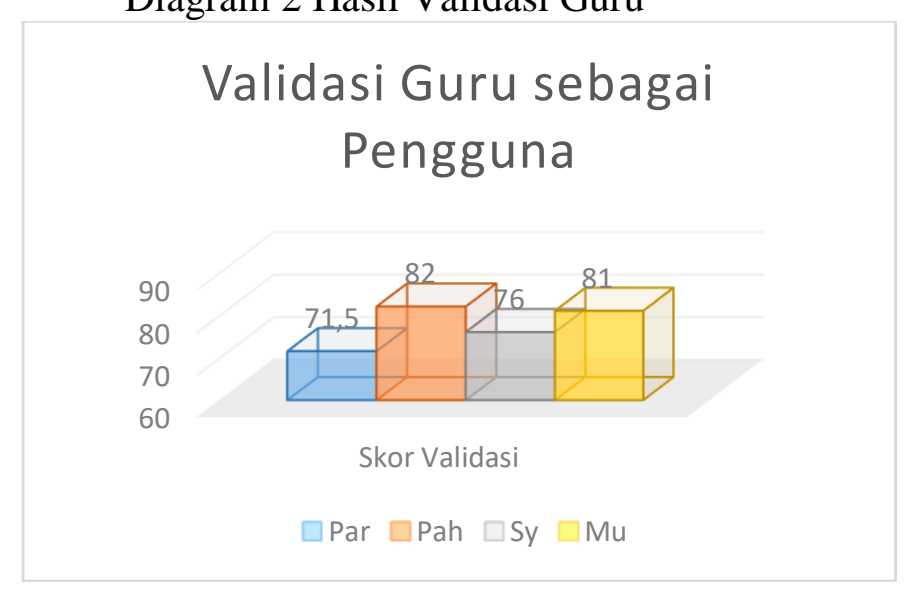

Diagram di atas menunjukkan skor validasi pengguna guru SDN kelayan Barat 3 dengan skor 71,5 dan 82 dengan kriteria (valid). Skor validasi pengguna guru SDN Kelayan Barat 2 Banjarmasin dengan skor 76 dan 81 dengan kriteria (valid). Dengan demikian, produk ini valid dan dapat layak oleh guru sekolah dasar. Hasil validator pengguna adalah siswa kelas V SDN Kelayan Barat 2 Banjarmasin sebanyak empat orang. Paparan data secara rinci sebagai berikut:

Tabel 3 Kriteria Pengguna

\begin{tabular}{|c|l|l|}
\hline No & Interval & Kriteria \\
\hline 1. & $81 \%-100 \%$ & Sangat Baik \\
\hline 2. & $61 \%-80 \%$ & Baik \\
\hline 3. & $41 \%-60 \%$ & Cukup Baik \\
\hline 4. & $21 \%-40 \%$ & Kurang \\
\hline 5. & $0 \%-20 \%$ & Kurang Sekali \\
\hline
\end{tabular}

Adopsi: Litsarini, dkk (2018)

Diagram 3 Hasil Validasi Pengguna Guru

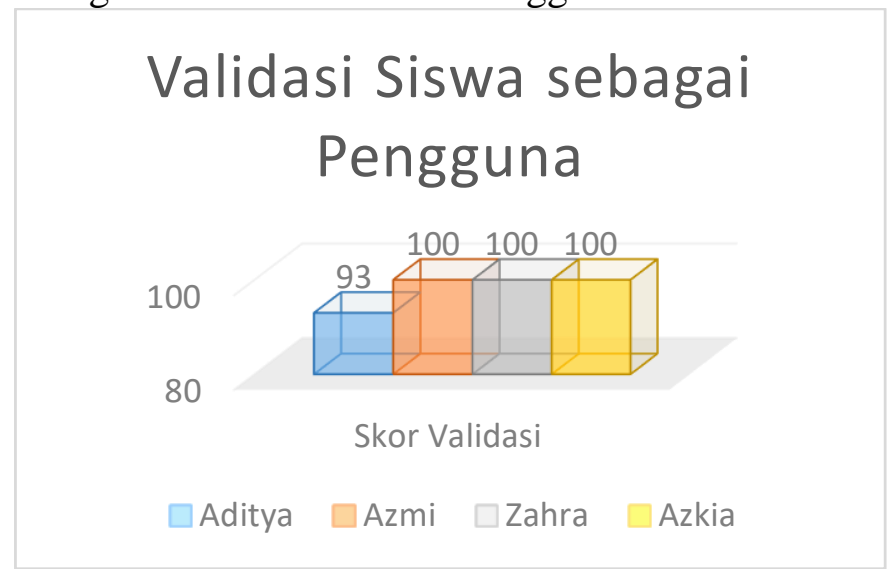

Kepala sekolah SDN Kelayan Barat 2 Banjarmasin, memberikan izin untuk mengundang empat orang siswa sebagai validator pengguna. Pemilihan empat orang siswa tersebut dengan pertimbangan bahwa mereka berdomilisi tidak jauh dari sekolah. Selain itu, pemilihan empat orang siswa agar tidak melanggar protokol 
kesehatan masa pandemik Covid-19 yang mengaruskan peserta didik / siswa untuk belajar di rumah. Alasan inilah yang menjadi pertimbangan bahwa pemilihan empat orang siswa SDN Kelayan Barat 2 Banjarmasin sebagai validator pengguna. Kegiatan validasi dilaksanakan di kelas, dengan mematuhi protokol kesehatan. Siswa yang berhadir menjaga jarak, menggunakan face shiled, masker, dan tidak bergerombol.

Diagram di atas menunjukkan hasil validasi pengguna siswa dengan nilai 93, 100, 100, dan 100. Nilai tersebut menujukkan kriteria sangat baik/ valid. Dengan demikian, buku suplemen ini dapat digunakan oleh siswa selaku pengguna. Hasil pelaksanaan penelitian ini masih sebatas validasi produk dan penyempuraan setelah di validasi oleh validator ahli dan pengguna. Perbaikan produk ini sesuai dengan saran validator dan pengguna. Perbaikan tersebut meliputi kesalahan pengetikan, typo dan beberapa kosa kata yang tidak pas. Namun, secara penilaian kuantitatif, produk ini valid dan layak digunakan.

Pada tahapan pengembangan hanya melakukan validasi ahli, disebabkan karena keterbatasan penelitian di masa pandemik covid-19. Pada penelitian ini memfokuskan pada hasil dari validator ahli dan validator pengguna. Untuk kegiatan. Developing testing berupa kegiatan menguji coba produk terhadap subjek pendidikan. Pada penelitian ini, kegiatan developing testing ditiadakan mengingat masa pandemik covid-19 meniadakan kegiatan pembelajaran luring di dalam kelas. Sebagai gantinya, pembelajaran di laksanakan dengan menggunakan daring dan takehome. Hal ini menyebabkan peneliti tidak dapat mengujicoba produk di dalam kelas.

\section{Tahap Penyebarluasan (Desseminate)}

Produk hasil pengembangan melalui kegiatan expert appraisal /validasi ahli. Namun, untuk kegiatan developing testing / uji coba tidak memungkin karena terkendala perizinan dari pihak sekolah. Kepala sekolah SDN Kelayan Barat 2 banjarmasin tidak mengizinkan untuk menguji coba produk dengan alasan kegiatan pembelajaran dilaksanakan secara daring di rumah. Selain itu, guru kelas V tidak berkenan untuk memberikan perlakuan di kelas mereka karena guru tidak memungkinkan untuk menggunakan sebagai sumber belajar. Guru sudah banyak memberikan penugasan mandiri kepada siswa, sehingga siswa tidak akan mampu mempelajari suplemen pembelajaran tersebut. Guru merasa tidak memiliki waktu yang luang untuk menggunakan produk tersebut, karena kegiatan guru didominasi dengan mengoreksi tugas-tugas siswa. Atas dasar itulah, kepala sekolah dan guru tidak mengizinkan untuk menguji coba produk dalam bentuk daring dan luring.

Produk pengembangan disebarkanluaskan di tingkat gugus Kelayan Barat Banjarmasin. Penyerbarluasan ini dengan mematuhi dan mempertimbangkan protokol Kesehatan yang berlaku. Penyebarluasan produk dilakukan dan difasilitasi KKG gugus Kelayan Barat Banjarmasin.

\section{Hasil Produk}

Produk yang dikembangkan melalui analisis kuantitatif menunjukkan skor dan nilai yang baik atau dengan kriteria valid, sehingga dapat digunakan dengan kriteria valid, dan menarik. Analisis kualitatif yang diperoleh melalui hasil koreksi validator menjadi bahan perbaikan produk. Setelah produk direvisi sesuai dengan saran validator, maka produk bersifat final.

776 BRILIANT: Jurnal Riset dan Konseptual

Volume 5 Nomor 4, November 2020 

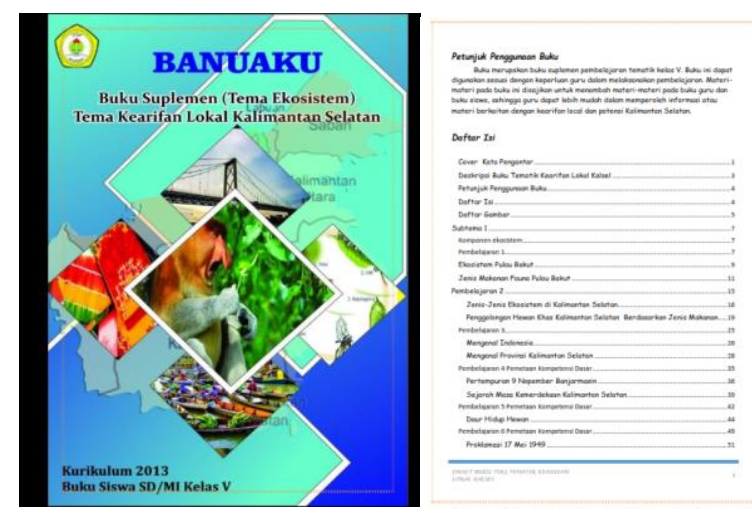

Gambar 1 Cover dan Daftar isi
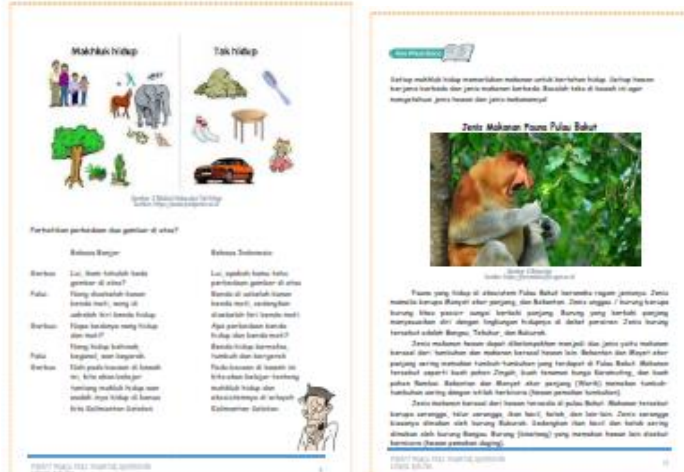

Gambar 2 Isi Buku PDF

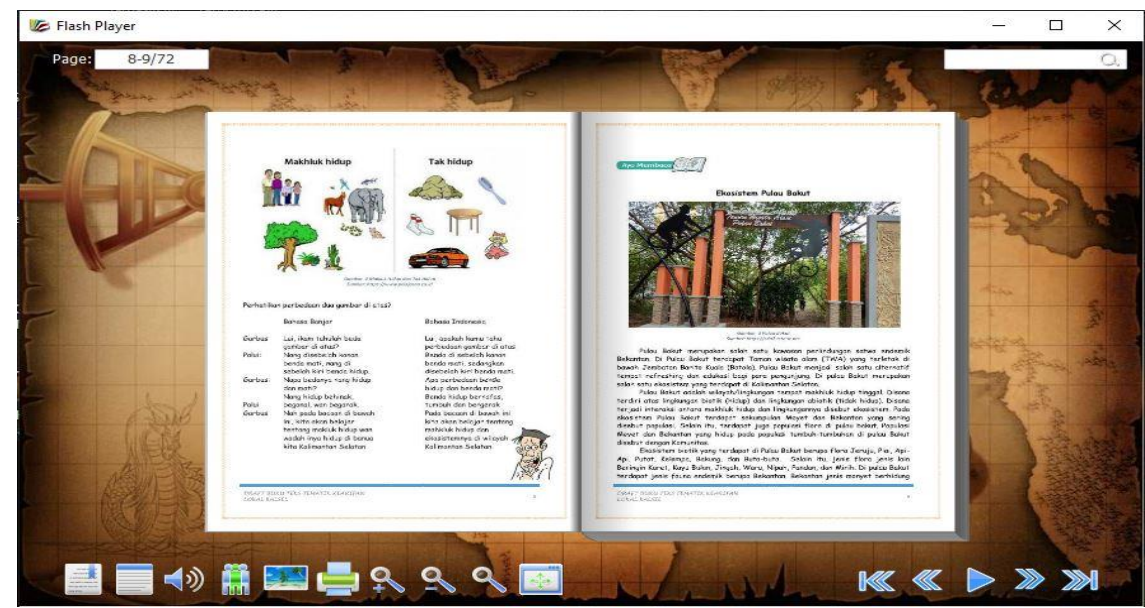

Gambar 4 Isi Buku Flipbook

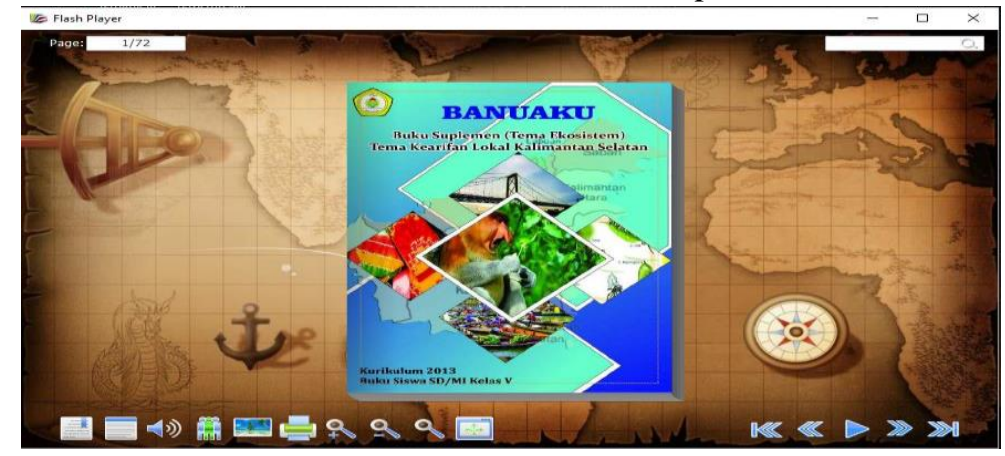

Gambar 5 Cover Buku Flipbook 


\section{PEMBAHASAN}

Penelitian pengembangan buku suplemen kurikulum 2013 berbasis Filpbook Tema Kearifan Lokal Kalsel pada masa pandemik Covid-19 merupakan suatu kegiatan penelitian penuh dengan tantangan. Tantangan bagi peneliti untuk mencari alternatif solusi pembelajaran menarik di masa pandemik tanpa melakukan interaksi sosial tanpa melibatkan jumlah peserta didik dengan jumlah yang banyak. Selain itu, tantangan bagi guru agar mampu menjadi lebih inovatif dalam melaksanakan pembelajaran secara daring. Hal terpenting, pengembangan suplemen pembelajaran ini menjadi alternatif pembelajaran di masa pandemik, sehingga peserta didik tidak mudah bosan dalam belajar di rumah.

Dalam pelaksanaannya, penelitian ini menggunakan model pengembangan Four D dikembangkan oleh Thiagarajan (1975). Penerapan ini melalui empat langkah sebagai berikut: define (pendefinisian), design (perancangan), develop (pengembangan), dan disseminate (penyebarluasan). Namun, dalam penerapan model Four D pada penelitian ini dimodifikasi dengan rasionalitas keadaan pandemik Covid-19. Modifikasi ini dilakukan karena membutuhkan waktu eksperimen yang lebih panjang, dan keterbatasan waktu (Miswanto, 2012:32). Modifikasi terbatas dilakukan karena masa pandemik Covid-19 yang menyebabkan katerbatasan peneliti dalam melakukan langkah-langkah pengembangan, sehingga ujicoba produk ditiadakan karena siswa tidak belajar secara luring (Dahlia, 2020).

Dalam proses pengembangan buku suplemen kurikulum 2013 melewati tahap-tahap pengembangan. Diantaranya tahap validasi ahli materi, ahli media, ahli bahasa dan validasi pengguna guru serta siswa. Untuk uji coba produk di tiadakan karena masa pandemik, kegiatan pembelajaran di kelas di tiadakan, dan digantikan pembelaran daring. Oleh karena itu, data yang digunakan untuk membuktikan validitas dan kemenarikan produk ini melalui hasil angket yang diberikan kepada validator ahli dan validator pengguna.

Hasil validasi ahli tersebut berbentuk data quantitatif menjadi patokan kriteria validitas produk yang dikembangkan. Hasil validasi ahli materi dengan skor 67 dengan kriteria (valid), ahli bahasa 56 dengan kriteria (valid), dan skor ahli media 68 (valid). Kriteria skor dari ahli materi, ahli media, dan ahli bahasa menunjukkan kriteria valid, sehingga produk ini dapat digunakan. Namun, pada lembar validasi terdapat catatan perbaikan guna perbaikan buku suplemen pembelajaran.

Hasil validasi pengguna guru SDN kelayan Barat 3 dengan skor 71,5 dan 82 dengan kriteria (valid). Skor validasi pengguna guru SDN Kelayan Barat 2 Banjarmasin dengan skor 76 dan 81 dengan kriteria (valid). Dengan demikian, produk ini valid dan dapat layak oleh guru sekolah dasar. Hasil validasi pengguna siswa secara eksplisit menunjukkan respon yang terhadap produk ini. hal ini senada dengan hasil penelitian Saputra \& Mushafanah, (2017) menunjukkan respon siswa terhadap implementasi penggunaan media koran melalui flipbook menunjukkan respon positif dengan 97,62\%. Hasil penelitian serupa yang dilakukan oleh Andani \& Yulian (2018) berupa pengembangan bahan ajar elektronik book berbasis flipbook menunjukkan validasi ahli 94,80\%, dengan kriteria sangat layak. Respon siswa terhadap bahan ajar elektronik ini $100 \%$, dengan kriteria sangat layak. Hasil penelitian serupa di masa pandemik Covid-19 yang dilakukan oleh Dahlia (2020) dengan mengembangkan model muatan lokal berbasis flipbook. Hasil validasi ahli

778 BRILIANT: Jurnal Riset dan Konseptual Volume 5 Nomor 4, November 2020 
menunjukkan skor 62, dengan kriteria sangat efektif. Hasil respon siswa melalui angket menunjukkan nilai 14, dengan kriteria sangat efektif.

Uji coba produk di tiadakan mengingat kegiatan pembelajaran di sekolah melalui daring. Pembelajaran daring dilakukan karena kebijakan pemerintah untuk menghindari penularan Covid-19 di lingkungan sekolah terhadap peserta didik atau warga sekolah. Meskipun uji coba produk tidak dilaksanakan, angket respon siswa terhadap produk tetap di sebarkan kepada siswa. Kegiatan ini lakukan agar siswa dapat menilai produk tersebut. Hasil validasi pengguna siswa dengan nilai 93, 100, 100, dan 100. Nilai tersebut menujukkan kriteria sangat baik/ valid. Dengan demikian, buku suplemen ini dapat digunakan oleh siswa selaku pengguna.

Hasil validasi berbentuk qualitatif menjadi acuan perbaikan konten buku suplemen kurikulum 2013. Data qualitatif diperoleh dari saran ahli materi, ahli bahasa, dan ahli media. Saran ahli materi berupa perbaikan dalam hal pengetikan kata, tanda baca. Saran ahli media tidak ada, karena sudah dianggap sesuai kriteria madia yang menarik. Saran ahli bahasa berupa perbaikan tanda baca, perbaikan kosa kata, perbaikan kalimat sesuai usia anak sekolah dasar. Saran ahli materi, dan ahli bahasa menjadi bahan perbaikan.

Hasil validasi pengguna berbentuk data qualitatif yang diperoleh dari angket terbuka. Dua dari empat orang guru memberikan saran terkait konten buku suplemen. Saran validator pengguna dari SDN Kelayan Barat 3 berupa konsistensi pengguna huruf pada daftar isi. Selain itu, validator pengguna dari SDN Kelayan Barat 3 memberikan saran terkait tanda baca, penulisan kata yang salah ketik, dan beberapa istilah atau kata. Hasil pendapat validator pengguna guru dijadikan bahan perbaikan untuk buku suplemen kurikulum 2013. Buku suplemen kurikulum 2013 diperbaiki sesuai saran validator ahli, dan validator pengguna.

\section{KESIMPULAN}

Penelitian pengembangan buku suplemen kurikulum 2013 tema kearifan lokal Kalimantan Selatan menghasilkan produk berupa buku suplemen pembelajaran yang dipadukan dengan aplikasi flipbook sehingga menghasilkan buku flipbook. Produk ini kembangkan melalui model Four D. Produk ini divalidasi olehi ahli materi dengan skor 67 dengan kriteria (valid), ahli bahasa 56 dengan kriteria (valid), dan skor ahli media 68 (valid). Dengan demikian, penilaian oleh ahli materi, ahli bahasa, dan ahli media menunjukkan produk ini valid dan dapat digunakan. validasi pengguna guru SDN kelayan Barat 3 dengan skor 71,5 dan 82 dengan kriteria (valid). Skor validasi pengguna guru SDN Kelayan Barat 2 Banjarmasin dengan skor 76 dan 81 dengan kriteria (valid). Dengan demikian, produk ini valid dan dapat layak oleh guru sekolah dasar. validasi pengguna siswa dengan nilai 93, 100, 100, dan 100. Nilai tersebut menujukkan kriteria sangat baik/ valid. Dengan demikian, buku suplemen ini dapat digunakan oleh siswa selaku pengguna. Hasil validasi ahli dan pengguna menunjukkan buku suplemen ini valid dan menarik sehingga layak digunakan untuk di kelas V sekolah dasar.

\section{SARAN}

Penelitian pengembangan buku suplemen kurikulum 2013 yaitu: 1) penelitian ini hanya sebatas pada validasi ahli dan validasi pengguna, sehingga untuk peneliti selanjutnya melaksanakan penelitian sesuai tahap model Four D. 2) produk ini digunakan oleh guru sebagai alternatif sumber belajar siswa kelas $\mathrm{V}$ 
sekolah dasar. Dengan demikian, keseluruhan langkah penelitian pengembangan dengan model Four D terlaksana secara komplet tanpa memodifikasi langkahlangkah model pengembangan.

\section{DAFTAR RUJUKAN}

Andani, Tri, Dika. \& Yulian, Muammar. 2018. Pengembangan Bahan Ajar Electronic Book Menggunakan Software Kvisoft Flipbook pada Materi Hukum Dasar Fisika di SMA Negeri 1 Panton Reu Aceh Barat. (JIPI) Jurnal IPA dan Pembelajaran IPA. Vol. 2, No. 1. Hal 1-6.

Astini, Ni Komang Suni. 2020. "Pemanfaatan Teknologi Informasi dalam Pembelajaran Tingkat Sekolah Dasar pada Masa Pandemi Covid19." Jurnal Lampuhyang 13-25.

Dahlia, 2020. Pengembangan Modul Interaktif Muatan Lokal untuk Kelas V Sekolah Dasar. Skripsi tidak diterbitkan. Banjarmasin: STKIP PGRI Banjarmasin.

Jamaluddin, Dindin, Teti Ratnasih, Heri Gunawan, and Epa Paujiah. 2020. "Pembelajaran Daring Masa Pandemik Covid-19 Pada Calon Guru:Hambatan, Solusi dan Proyeksi." Lembaga Penelitian, dan Pengabdian Kepada Masyarakat UIN Sunan Gunung Jati.

Kristiawan, M. (2014). A Model for Upgrading Teachers Competence on Operating Computer as Assistant of Instruction. Global Journal of Human Social Science Research.

Kusuma, Wijaya Jaka, and Hamidah. 2020. "Perbandingan Hasil Belajar Matematika dengan Penggunaan Platform WhatsApp Group dan Webinar Zoom dalam Pemelajaran Jarak Jauh Pada Masa Pendemik Covid-19 ." Jurnal Pendidikan Matematika 97-106.

Listyarini, Ikha., Saputra J.H., Basyar, Khairul. 2018. Pengembangan Media Digital Book Berbasis Flipbook Maker Materi IPA Kelas V di Sekolah Dasar. Semarang: Lembaga Penelitian dan Pengabdian kepada Masyarakat Universitas Negeri Semarang.

Miswanto. 2020. Pengembangan Buku Siswa Bercirikan Penemuan Terbimbing Materi Eksponen. Tesis tidak diterbitkan. Malang: PPS Universitas Negeri Malang.

Saputra, Januar, Henry. \& Mushafanah, Qoriati. 2017. Pengembangan Media Koran Materi IPA di Sekolah Dasar melalui Flipbook Maker. Seminar Nasional Hasil Penelitian (SNHP)-VII. Semarang: Universitas PGRI Semarang.

Thiagarajan, Sivasailam, D S Semmel , and M I Semmel . 1974. Instructional Development for Training Teachers of Exceptional Children. Washington DC: National Center for Improvement Educational System.

Peraturan Menteri Pendidikan dan Kebudayaan No. 22 Tahun 2016 Tentang Standar Proses Pendidikan.

Prostowo, A. (2014). Pengembangan Bahan AjarTematik. Jakarta: Kencana. 